\section{THE BRITISH ASSOCIATION MEETING AT EDINBURGH}

\section{SECTION A.}

On Temperative Equilibrium of an Enclosure in sohich there is a Body in Visible Motion, by Prof. Balfour Stewart, F.R.S.It is now several years since Prof. Tait and the author of this paper came jointly to entertain the belief that there is some transmutation of energy, the exact nature of which is unknown, when large bodies approsch and recede from one another. It is desirable to vindicate an idea of this nature, both from the theoretical and the practical point of view-that is to say, we ought, if possible, to exhibit it as a possible deduction from those laws of nature with which we are already acquainted; and, on the other hand, it ought to be supported by observations and experi ments of a new kind. In our case the experiments and observations have been of a difficult nature, and are yet in progress, it is therefore premature to bring them before the notice of this section. A theoretical vindication of the idea has been obtained by Prof. Tait, and more recently one has occurred to the author of these remarks, which he now ventures to bring before the section. Men of science are now sufficiently weil acquainted with. Prevost's theory of exchanges and its recent extension. We know that in an enclosure, the walls of which are kept at a constant temperature, every substance will ultimately attain the very same temptrature as these walls, and we also-know that this temperatureequilibrinm can only be brought about by the absorption of every particle being exactly equal to its radiation, an equality which must separitely hold for every individual kind of heat which the enclosure radiates. This theoretical conclusion is sup. ported by numerous experiments, and one of its most important applications has been the analysis of the heavenly bodies by means of the spectroscope. Let us now suppose that in such an enclosure we bave a body in visible motion, its temperature, however, being precisely the same as that of the walls of the enclosure. Had the body been at rest, we know from the theory of exchanges that there would have been a perfect equilibrium of lemperature between the enclosure and the body; but there is reason to believe that this state of temperature-equilibrium is broken by the motion of the body. For we know both from theory and experiment that if a body, such for instance as a star, be either rapidly approaching the eye of an observer or receding from it, the rays of the body which strike the eye will no longer be precisely the same as woald have struck it had the body been at the same temperature and at rest ; just as the whistle of a railway engine rapidly approaching an observer will have to him a different note from that which it would bave had if the engine had been at rest. The body in motion in the enclosure is not therefore giving the enclosure those precise rays- which it would have given it had it been at the same temperature and at rest on the other hand, the rays which are leaving the enclosure are unaltered. The enclosure is therefore receiving one set of rays and giving out another, the consequence of which will be a want of temperature-equilibrium in the enclosure-in other words, all the various particles of the enclusure will not be of the same temperature. Now, what is the consequence of this? The consequence will be that we can use these particies of different temperature so as to transmute part of their heat into the energy of visible motion, just as we do in a steam engine; and if it is allowable to suppose that during this process the moving body has retained all its energy of motion, the result will be an in crease of the amount of visible energy within the enclosure, all the particles of which were originally of the same temperature. But Sir W. Thomson has shown us that this is impossible; in other words, we cannot imagine an increase of the visible energy of such an enclosure unless we acknowledge the possibility of a perpetual motion. It is not, therefore, allowable to suppose that in such an enclosure the moving hody continues to retain all its energy of motion, and consequently such a body will have its energy of motion gradually stopped. Evidently in this argument the use of the enclosure has been to enable us to deduce one proof from the known laws of heat and energy, and we may alter the shape of the body without affecting the result; in other words, we should expect some loss of visible energy in the case of cosmical bodies approaching or receding from one another.

Observations on Water in Frost rising aguinst Gravily, rather than Frresing in the Pores of Moist Earth, by Prof. James Thomson, LL. D., of Belfast. In this paper Prof. Thomson, in continuation of a subject which he had brought before the British Association at the Cambridge Meeting in 1862 on the
Disintegration of Stones exposed to Atmospheric Influences, addaced some remarkable instances which he had since carefully observed. In one of these observed by him in February 1864 , ho showed that water from a pond in a garden had in time of frost raised itself to heights of from four to six inches above the water surface level of the pond by permeating the earth bank, formed of decomposed granite, which it kept thoroughly. wet, and out of the upper surface of which it was made to ascend by the frost, so as to freeze as continuous columns of transparent ice rather than that it would freeze in the earch pores. From day to day during the frost the earth remained unfruzen, while a thick slab of columnar ice formed itself by new water coming up from the pond, and insinuating itself forcibly under the bases of the ice columns so as. to. freeze there, pushing them up, not by hydranlic pressure, but on principles which, while seeming to have been previously not noticed, appear to involve considerations of scientific interest, and to afford scope for further experimental and theoretical researches.

\section{SECTION B.}

A REFORT On the Publication of Abstracts of Chemical Papers was read by the secretary (Dr. Thorpe). The com. mittee, which consisted of Profs. Williamson, Roscoe, and Frankland, having charge of the matter, said they were glad to be able to announce that regular monthly reports of the progress of chemistry have been published since April last by the Chemical Society. These reports have been rendered as far as possible complete, by giving abstracts, more or less full, of al] papers of scientific interest, and of the more important papers relating to applied chemistry. The abstracts have been made by chemists, most of whom are members of the Society, whose zeal for science has induced them to undertake the work for the small honorarium which the Council has been able to offer. A numerous Committee of Publication has been formed, whose members gratuitously undertake the revision of proofs, and a comparison of abstracts with the original papers. The vommittee feel that their thanks are due to those gentlemen engaged in the work. for having already so far succeeded in accomplishing a. task of such difficulty and importance, and they confidently hope that their continued exertions will still further perfect the details of the scheme, so as gradually to increase the usefulness of the-report. It is right to state that the funds of the Chemical Society, available for the purpose of the report, although so opportunely aided by a grant of rool. from the British Association, were insufbcient to defray the necessary ex enses, and that voluntary contributions to the amount of upwards of 200l. have been received towards the cost of publication for the first year up to April 1872. There is good reason to believe that the expectations entertained of the usefulness of these reports will be fully realised by their continuance on the present system; and that they will be found largely to conduce to the progress of the science wherever the English language is spoken.

Prof. Williamson said it had long been felt in England that some equivalent was needed for those admirable annual reports which have long been published in Germany, and of which the value was so very great to workers in chemistry. To meet that want was the object the committee had in view.

A vote of thanks was given Prof. Williamson for his exertions in connection with the matter.

Dr. Thorpe read a paper On Phasphorus Chlorides. He said he had attempted to prepare the missing oxicblorides analogous to those obtained from vanadium by Roscoe, but without success. When the phosphoryl trichloride is heated with zinc in a sealed tube, the oxygen is withdrawn and phosphoric chloride is obtained. He had also prepared sulpho-chloride of phosphoras by the action of sulphide of phosphorus on the penta-chloride of phosphorus.

Mr. Pattison Muir made a communication On an Antimony Ore from the Thames, New Zealand. The specimen analysed was beautifully crystallised and almost chemically pure antimony sulphide, containing only traces of arsenic and antimony. Mr. John Dalzell communicated a paper On Stuphur Dichloricle. $\mathrm{He}$ has repeated Hübner's experiments, and finds that the compound actually exists at low temperatures. Dr. Wright gave a résume of his researches On the Derivatives from Codria. An account of these investigations has already appeared in our columns. Mr. Tichborne read a paper On the Dissoriation of Molecwles by Heat, and showed some very pretty lecture experiments on the subject. Mr. J. G. Buchanan read a paper illastrated by diagrams On the rate of Action of Casstic Soda on a. Watery Solution of 
Chloracetic Acid. He has determined the rate at which chloracetic acid suffers decomposition, when heated simply with water or with caustic sods in a sealed tube. The following papers were also read :-Prof. A pjohn, Sone.Remorks on the Froxintate Analysis of Saccharine Matters; Dr. Gladstone, On Crystals of Silver; Mr. Braham, On the Crystallisation of Metals by Electricily; Mr. J. S. Holden, On the Aluwistous Jron Ores of Co. Antrim; Prol. Maskelyne, On Dafrenite and a New Mincral from Cornwall, and on Localities of Diopsase; Rev. Mr. Highton, On a Mehod of Preserving Food by Muriatic Acid; Mr. Wanklyn, On the Constitution of Salts; Mr. Harkness, On a Method of. Testivg Wood Naphtha.

\section{SECTION C}

Mr. Carruthers, F.R.S., read a paper by Mr. Grieve On the Position of Organic Nemains near Burntisland, and also a paper by himself On the Vegrtable Contents of Masses of Limestone occurring in Trappear Rocks in Fifeshire, and the conditions nuder which they are preserved. Large masses of plants which formed the coal bad been enclosed in the trappean ash, and subsequently calcified by the large amount of lime contained in the rocks. Mr. Camruthers considered that these fragments were enclosed in a peaty condition, because the mass was penetrated in every direction by roots, showing the existence of regetation on this soil. The attention of Mr. Grieve was first directed to the specimens by observing on the shore large masses of limestone which had been polished by the drifting sand. The action of this sand wss well shown in the neighbourhood, even the hard basaltic rocks having been polished by it. Mr. T. M'K. Hughes said that after what hadbben brought out in regard to the action of the drifting sand, they must take care not to attribute the polishing of rocks in every instance to glacier action.

The second meeting of Section C. was opened by Mr. Pengelly, who read the Sevonth Report on the Kent's Cavern Exfioretions. His clear and lively lecture drew together a good indience. Commencing with some general remarks on the history and working of the Cavern, in order to make the subject clear, he pointed out the usual section to be, in descending order:-1. Black mould, containing many objects of recent date, and some of Romano-British times; also remains of animals still living, or which lived in historic times. 2. Granular stalagmite, containing remains of extinct animals, and also a human jaw. 3. Cave earth, yielding a harvest of extinct jemains, also flint implements. 4. Crystalline Stalagmitic floor, and Preccia formed of rocks from distant hills; bears only have Leen obtained from these. He then described the work done during the past twelve months, showing what new passages had heen opened, and the aumber of species which had been obtained. They, included hyæna, horse, thinoceros, Irish elk, ox, ceer, badger, elephant, bear, fox, lion, reindeer, rabbit, bat, wolf, dog, \&c. Many of the bones were gnawed by hyrena, others were marked by rootlets encircling them. Aitogether, Ebout 2,2co teeth and bones and 366 flint implements and flakes had been obtained since the last year's Report was read.

The Contents of a Hyena's Den on the Great Donuard, Whitritirch, Ross, Herefordshire; were pointed out by the Rev. W. S. Symonds, F.G.S. He remarked that the section of the deposits was-I. Snperficial soil and stalactitic matter with Koman (?) pottery and human bones: 2. Thin band of stalactitic matter. 3. Cave earth, containing flint flakes and chips, stone ingtruments, teeth and bones of numerous mammals either extinct or not now inhabiting the district, as the cave lion, cave bear, hyaena, mammoth, long-hatred shinoceros, fossil horse, \&c. 4. Stratified sand and silt, with rolled pebbles. 5. Thick floor of stalagmite, and cave earth separated every few feet by layers of stalagmite, containing flint flakes.

Mr. Vivian, referring to the length of time daring which man had existed on the earth, thought he might have existed for about \& million years. Prof. Hull remarked that there was no evidence as yet to bring back man to the Glacial epoch, and therefore opinfons about the high antiquity of man should be reserved. Mr. Prestwich concurred with Mr. Hull, but said there was no doubt that man followed very closely upon the Glacial period.

Mr. L. C. Miall read a paper On Some. Further Experiments and Remarks on the Contortion of Rocts, describing results obtained by sobjecting limestone, flagstone, slate, and plaster of Paris to forces of low intensity but of long continuance. Mountain anc, magnesian limestone proved to be indefinitely plastic ; slate slightly elastic, but almost incspable of permanent deflection. Remarks on some cases of superficial and modern contortions were appended to the paper.

Prof. Hull and Mr. W. A. Traill, B A., of the Geological Survey of Ireland, read a paper On the Relative Ages of the Grantic, Plutonic, and Volcanic Rocks of the Moserne Moun. tains, Down, Iroland. They first pointed out the presence of two varieties of granite, differing, as Prof. Haughton had shown, both in composition and origin; the soda granite of Slieve Croob (consisting of quartz, orthoclace, albite, and mica) being of metamorphic origin, and the potash granite of Mourne (consisting of quartz, orthoclase, albite, and mica) being eruptive. The relative, and as far as possible, the actual ages of these granites, rimained to be determined, which the authors considered might be determined by a consideration of the basaltis and felstone-porpbyry dykes, by which the district had on several occasions been invaded. The conclusions thus derived were that the granite of Mourne was newer than that of Slieve Croob by a long interval, and that while the former was probably Mesozojc, the latter was of Palaeozoic age.

The third meeting of the Geological Section was held on Saturday August 5. The first paper read was by the Rev. Dr. Hume On the Coal Bedis of Panansa, in reference mainly to thei economic importance. The author drew attention to the discovery of a series of seams in the Isthmus of Panama. Analysis proved the coal to contain about 75 pey cent, of carbonsceous matter, the remaining portion being water and ash; it had a fair heating and a large illuminating power. There are four points where the coal reaches the surface of the thickness of git., 12ft., and with intervening streales of shale and clay $25 \mathrm{ft}$. ; is, however, improves in value at greater depths. He pointed out the great importance of this coal, in the event of a canal being made through the Isthmus.

The relation of bealth to certain geological formations was treated of by. Dr. Moffatt. He remarked that the district in which he lived consisted geologically of the Carboniferous and of the New Red Sandstone system; that the inhabitants of the former were engaged in mining and agriculture, and those of the latter in agriculture chiefly. Anamia, with goitre, was very prevalent among those persons living on the Carboniferous system, while it was almost unknown among those on the New Red Sandstone; and phthisis was also more prevalent anong the former than the latter. $\mathrm{He}$ then gave some statistics as to the diseases prevalent among the counties of Chester, Flint, and Denbigh, and stated that the practical deductions to be drawn from the inquiry were, that all young persons living on a Carboniferous formation. having symptoms of incipient goitre and anremia, ought to be moved to a soil upon red sandstone, and persons of strumous habit ought to reside upon sandstone at an elevation of at least 800 or $\mathbf{I}, 000$ feet above the sea. In the discussion which followed the reading of this paper Mr. G. A Labour mentioned a Carboniferous district in Northumberland containing a thin bed of limestone where the people suffered from goitre. Sir Richard Griffith remarked that goitre was unknon n in Ireland, although they had plenty of Carboniferous rocks. Professor Hall agreed with Dr. Moflat respecting the bealthful character of the New Red Sandstone.

A paper was then read by the Rev. J. F. Blake On the York. shire Lias and the Distribution of its Aminontites.

Some relics of the Carboniferous and other old land surfaces were described by Mr. Henry Woodward.

\section{SECTION D,}

THE Committee for the Close Time for Birds, reported by the Rev. Canon Tristram, LL. D., that it had gone on year after year endeavouring, as well as it conld, to influence public opinion on the question of the preservation of indigenous life in this country. At the time of its appointment there was no protection whatever for any creature not coming under the Game-laws. Anything not game was treated by law as vermin. A curious case had arisen in regard to Pallas's sand grouse. That bird made its appearance on the east const of England, and if it had been allowed to breed on the sand-pits of Durham, Yorleshire, and Lincolnshire, no doubt it might have become an in. digenous bird. He (Dr. Tristram) summoned some people for shooting it out of season in the spring of the year; but it was decided that, being sand grouso and not Scotch grouse, it was beyond the benefit of the laws. The committee had to congratulate the Association two years ago on having succeeded with very 
Iittle difficulty in steering a Bill safely throagh all the perils of Select Committees of both Houses of Parliament. That Bill, however, was shorn of its fair proportions; and although it went into the House a Bill for the Protection of Indigenous Animals, it came out an Act for the Preservation of Sea-Fowl. The seafowl had borne their testimony to the sucoess of the Act so far, and it was something to have to say that within the last year the numbers of sea-fowl that had bred on the Yorkshire const were, at least, three times as many as they were two years ago. That success was a great benefit, at the same time, to those who made their living by sea-fowl, because purveyors of feathers and eggs had fouad that the Sea-Fowl Aet had actually very largely in creased not only their profits, but their supply, in the same way as the improvement of the Salmon Acts had restored the salmon to rivers from which it had been almost extirpated. The committee, therefore, finding there was a unanimous verdict in favour of the Act regarding sea-fowl, strongly recommended the Association to endeavour to extend the Act in two ways. This they proposed to do next session by introlucing amending clauses. One object to be aimed at was to extend the $\boldsymbol{A}$ et to all wading birds and all web-footed birds good for human food. It was desirable to protect the sandpipers, the plovers, the lapwings, and the whole of the duck tribe, which were being rapidly exterminated. Having suoceeded in that, the committee should next endeavour to have British law on the subject assimilated to the sternly restrictive laws of every other civilised country, except Holland, Greece, and Turkey-those three being the only countries in the world professing to be civilised which had not a close-time for all creatures.

ORnirnology, --Prof. Duns, D.D., New College, Edinburgh, read a paper On the Raver Raptorial Birdt of Scatland; the four following propositions were stated :- -1 . That species occur in pairs, often at long intervals, in localities where they have long since ceased to breed, but where they have been at one time not: uncommon. 2. The geographical range of stragglers seems to widen with the lapse of time. 3 . Certain species have greatly increased in recent times over wide districts where they were comparatively rare 4 . Year by year the raptorial binds of Scotland are becoming fewer. These positions were all trezted of in the paper, which, not giving specific characteristics or descriptive details, yet pointed out all the chief sources of information and enumerated all the localities. $R$. Sibbald's list in "Scotia Illustrata," 1684 , and the many that intervened between it and the author's own lists collected during the last thirty years, were all referred to, and the conclustion come to was that most of the langer raptorial birds were rapidly disappearing from Scotland, and that even the smaller forms which were very common in the southern and central districts were yearly becoming rarer. The author also expressed his belief that both the farmer and the game preserver wonld lose much when between them they succeeded in destroying all the hawks and owls.

Icruyotocy.-A paper was communicated by Colonel Play. fair, H. B.M. Consul-General at Algiers, On the Bydrographical System and the Fresh Water Fish of Algeria. After describing certain interesting features in the physical configuration of the country, the paper went on to state that in the rivers fowing to the Mediterranean there were sixteen species of fish, only three of which were common to the whole region, one being the common eel. There were eleven species peculiar to the littoral of Algeria, among wbich was a small trout. The common gold fish, which was very common, was not a native of Algeria, but was supposed to have been introduced by the caprice of a certain Sultan many centuies ago. It was now, however, universal in the streans. The plateau had only afforded seven species, one of them being the same as a South African species. In the Sahara there were some peculiar species. The upper part afforded two species, one being the common eel, and in the lower region two species were found in the salt lakes, and had been frequently ejected by the Artesian wells. It had been concluded that these latter species inhabited a vast subterranean sea occupying the bottom of the Sahara depression. The question had to be remembered that their undergronnd life was simply an episode in the voyages they made between one well and another. When they reached a well they were either forced up or by instinct came to the surface. Owing to the shortness of the rivers and their being extremely rapid in their upper portion, the physical conditions were not such as would acmit of the intro- duction into them of the true salmon with any prospect of success.

Mr. C. W. Peach exhibited some apparently tailless trout which had been sent to him by Mr. Colin Hay, distiller, of Ardbeg, Islay. They were taken in Lochmaorichen, in Islay. That loch was about $\mathbf{r}, 000$ feet above the level of the sea, and not above one acre in extent. It was so shallow that a man could wade through it, and had a stony bottom, with a few weeds. Although it was surrounded by other lochs, these tailless trout were found only in it. The whole of them were "docked," and Mr. Mackay, a keen sportsman, who has fished it often for thirty years, never canght one with a perfect tail. They are in excellent condition, being fed on the small crusta. ceans which are abundant in the loch. Mr. Peach further stated that Mr. Hay was albout to add to his kindness by procuring a further supply of fish, if possible, from the fry to the adult state. $\mathrm{He}$ also intended to transport some of the "docked" trout to a loch at a short distance, in which trout had never been taken, and try to rear a stock from them, and see whether they would all remain "tailless.

Dr. Grierson said that, at the mines of Wauloch-Head, Dumfriesshire, and Lesdhills, Lanarkshire, there were streams coming from the shafts in which trout withont tails were frequently got, as also trout with deficient fins. The fish referred to were, moreover, frequently blind. Specimens of these fish were to be forwarded to Professors Turner, Traquair, and Dr. Günther for examination.

Mr. A. G. More exhibited some brown trout taken in salt water. It was not, he thought, generally known that the common or brown trout of fresh-water streams was an occesioual visitant to the salt water. The salmon and the sea-trout, and the sewin or Welsh sea-trout, descended regularly to the sca after they had finished breeding in fresh water; but the common brown tront had seldom been observed under the same circumstances. In Scotland $\mathrm{Mr}$. Peach, who had an extensive experience and knowledge of marine zoology, assured him that no instance of the kind had come under his notice, save once, when he found a river-trout in the stomach of a cod-fish. Possibly that trott was captured in salt water, but it might have been dropped by a cormorant, or have been swrept down the river in a food either weak or possibly already dead. In the west of Ireland-in the counties of Donegal, Sligo, Limerick, and Kerry, Mr. More had ascertained, partly through others and partly from his own observation, that the river-trout spontaneously frequented the salt water at the months of the rivers. The brown trout captured in sait water differed from their usual condition in having brighter and more sitvery scales, something like those of the young salmon in the smolt condition. Mr. More would like it to be ascertained if these trout were brown trout "pure and simple," or hybrids.

Prof. Duns exhibited a specimen of the spiny shark, Echino rhinus spinosus, Blain, which had been taken at Exrlsferry, near Elie, Fifeshire, in the February of this year. He also mentioned that a specimen had also been taken in January 1867 near Boness, Linlithgowshire.

Dr. C. Lütken described a new genus of fish belonging to the Gamily of the sea-devils, allied to, and, in fact, almost intermediate between the curious genus Melanocetus discovered some yerrs since by $\mathrm{Mr}$. Johnson at Madeira and the monstrous Ceratins, which, until the discovery of Mr. Johnson, was the best known example of the Apodal Lophioids. Of the third genus of the almost blind apodal deep sea Lophioids, it was strange that the Greenland seas should have already possessed a species, o. himantolophius, described many years ago by the senior Reinhardt from a mutilated specimen, but which description bad been almost forgotten by recent icthyologists. Among the characters distinguishing this genus Oneirodes, there is one both peculiar and suggestive, viz., the curious development of the head of the first dorsal fin-ray, which, with its tentacles, pigmental spots, \&c., gave the impression of, as it were, a mimicry of the head, say, of a Nereis. It would not be very wondetful if it were really intended to allure other rapacious fishes, and if the old stories of the angling propensities of the "fishing frog " were found to contain more truth than is generally believed. The new species O. eschrichtii was taken at Greenland.

Entomology.-Mr. Roland Trimen, F.L.S., F.Z. S., read a note on a curious South African grasshopper," Trackyptra bufs,

* Dethuen's "Wanderisgs in the Wilderness," and edition, 18,8 , App. p. 372 , pl, II., fig. 3 . 
White, which mimics with much precision the appearance of the stones among which it lives.

He commenced by observing that some tendency existed to separate too widely those cases of mimicry where one animal imitated another from those in which an animal closely resembled either some part of a plant or some inorganic object; and expressed the opinion that these two sets of cases were wholly one in kind, the evident object in all being the protection of the imitator.

Describing a visit paid to the vicinity of Grahamstown in search of thss insect, be observed that it was a work of considerable difficulty to distinguish the grasshoppers from the stones, and he was engaged for half an hour in careful search over a known station of the species before discovering an example. He noted the further most interesting fact, that, in certain spots (often only a few scuare yards in extent) where the stones lying on the ground were darker, lighter, or more mottled than those generally pre. valent, the Trachypetra found among such stones varied similarly from the ordmary dull ferruginous-brown colouring in imitation of them.

It was pointed out that the close imitation of the stones was mainly effected by the modification of the dorsal sbield of the prothorax, which is, with the whole thorax, much flattened and widened, and is further much produced posteriorly, and has its surface roughened or granulated in close resemblance to the surface of the stones.

In conclusion, he called attention to the bearing of the case of this insect on the question of the origin of species; and in putting the alternative whether the peculiar station of the Trachypeira had been specially prepared for it immediately before or simultaneously with the creation of the insect, or whether, on the contrary, the insect had been very gradually modified by natural selection in imitation of the stones for the purpose of concealment, he expressed his decided opinion in favour of the latter hypothesis.

Specimens of the insect wereexhibited in association with some of the stones among which they were captured, and the very close resemblance between stones and insects excited general remark. $\mathrm{Mr}$. Trimen observed that in nature the mimicry was more effective, the colours of the dead instects having faded considerably, and the shritiking of the abdomen having caused the hind-legs to be much more apparent than was the case in living examples.

Echinoderms. - Prof. Wyville Thomson read a paper On the Structure of the Crinoids, to which it would be impossible to do justice in a hrief summary. He proposed to make as primary divisions of the family the Astomata and Peristomata. Dr. Litken of Copenhagen remarked on the great interest of the paper, and referred to Prof. Wyville Thomson's earlier and excellent memoirs on the development of a species belonging to this family. In a paper On the Palcontological Relations of the Fauna of the North Attantic, Prof. Wyvilie Thomson exhibited and described a re. markable new genus possibly related to the Diademida, in the corona of which the plates overlapped, and which, when taken out of the dredge, rolled about like a soft egg; this was called Calverio hystrix. The Pedicellarixe were most beautiful objects, and the species is one of the most remarkable of all living Echinoids. A brautiful recent species called Purporatus of the genus Porosidaris wasalso exhibited, as alsospecimensof Brissinga, Pourtaleria, and Rhizocrinus. A choicer assemblage of rare and remarkable forms was probably never before exbibited to Section $D$, and it is not possible to refrain from mentioning that most of them will be described and figured in an early number of the Proceedings of the Zoological Society of London.

Celenterates.--Dr. Charles Lütken of Copenhagen, in introducing to the notice of the department a recent addition to the fauna of the Arctic region, said they would know that the progress of modern science bad given an increased interest and im. portance to the knowledge of Arctic forms. Naturalists were now busily engaged in looking for the remains of the vegetable and animal kingdoms left in the sedimentary deposits from the glacial epoch in which an immense ice-field had covered a great part of the earth. One of the latest discoveries in Scandinavin was that of a fresh-water deposit at the bottom of a great bog, coniaining the relics of a truly Siberian vegetation. On the onher hand, recent investigations, for which they were in part irdtbted to the British Government and British naturalists, bad shown that many of the lower animals, hitherto thought only to inhabit the Arctic Seas, had a very great geographical distribution. For a long time the seas of Greenland bad been one of the principal sources of our knowledge of Arctic life. It was about the only country, with the exception of the most northern part of Norway, within the Arctic Zone, where there was estab. lished a regular colony with a staff of ofticials, among whom there was always to be found one or more who were anxious to make their situntion profitable to science, and the directors and officers of the Museum at Copenhagen always encouraged these efforts with the view of collecting at Copenhagen as ample material as possible for the study of Arctic life. These efforts have been in later times rivalled by those of the Swedish Government, but their own efforts were greatly promoted by the circum. cumstance that the profits of the colonisation of Greenland were derived almost solely from the revenues got from the rich animal life, and that the Esquimaux were very acute observers of that nature from which they also derived their whole sustenance. He now submitted to the notice of the department a new species of Antipathes ( $A$. arctica) found lately in the stomach of a Greenland shark; it belonged to a tribe of corals hitherto believed to be exclusively inhabitants of the warmer seas, not being previously found north of the Mediterranean or South Carolina. He was now informed by Prof. Wyville Thomson that species of that genus did come to the surface during his late dredging expedition in the North Atlantic. This discovery, in addition to that of the Lophioid fish described above, indicated that the treasures of the Arctic Seas were not yet exbausted, and ougbt to stimulate further attention to them. Prof. Wyville Thomson and others took this occasion to state their admiration at the perfect order and care with which the Scandinavian Museums were kept, and their estimation of the great kindness shown by the officers of these Museums to naturalists in this country in sending over for examination complete series of different forms of Arctic life.

Dreiging.-Mr. W. Saville Kent sent an account of the zoological results of the 187 o dredging expedition of the yacht Norna off the coasts of Spain and Portugal.

Rev. R. B. Watson gave a very graphic account of the trials and troubles be had encountered in dredging at Madeira, and appended to his paper a list of the mollusca met with by him in Madeira

Mr. A. G. More also submitted to the department some accaunt of a recent dredging expedition which he had made to Bantry and Kenmare Bays.

\section{SUB-SECTION. - ANTHROPOLOCY.}

IN the anthropological department on Monday, August 7, Prof. Turner presided, and there was again crowded attendance throughout the day. The first paper was read by Mr. J. S. Phene On the Mannes's and Customs of the Early Inhabitants of Britain, doduced from the remains of their Touns and Villages. He drew attention to two prominent points, the universality of the circle, curve, or oval, in all the earliest British remgins and the similarity of the physics of the various localities where British remains are still traceable, arguing that though divided into trities, yet the inhabitants at the time were one people. In alluding to the physical features of their settlements, he pointed ont that a conical hill towards the east, with a stream between it and the settlement, seemed an indispensable condition in selecting a place of abode, and where hills did not naturally exist they had been formed with great labour, as the Castle Hill at Cambridge. He assumed the object of proximity of the hill was for facility of worship, and the separation by the stream was indicative of purity of sacred separation. He believed that our great cities had been founded on thege places, chosen by our so-called bar. barian ancestors, and quoted Edinburgb, with Arthur's Seat as the place of worship, and Holyrood as the site of habitation, in illustration of his views.

Mr. Phené also read a paper On art Expondition for the special Investigation of the Hebrides and Wert Highlands in search for Evidences of ancient Serpent Worship, and assigning to this worship the sbape of many mounds he had examined in Scotland. This paper cansed an animated discussion, in which Mr. Boyd Dawkins remarked that there was no invariable relation between the sites of ancient habitation and the neighbouring hills, sush as Mr. Phené had inferred. The dwellers in Britain before the arrival of the Normans, lived in hut circles, placed sometimes on the tops of hills and at others in the bottom of valleys, but in all cases they chose a soil though which the rainwater could easily pass. This was obviously the result of their not wishing to be flooded by the rains of winter. We know next to nothing, he stid, of their habi1s and modes of life, but the remains of the animals round their habitations proved that 
they lived on their flocks and herds as well as by the chase. The presence of querns, also, showed that they were pastornl. Besiles the ox and horned sheep and the pig, they ate fox, wild cat, and horse, and even the dog, and, to speak in general terms, any other animal they could get hold of. About their religion or symbolism nothing was known.

Dr. Archibald Campbell said he had seen a great deal of serpent worship in India, and on returning to his native Highlands, he had made numerous inquiries as to the traces of serpent worship there, but none of the people he had asked coald give any clue.

Dr. Grierson remarked that he did not consider Mr. Phené had brought forward any evidence to prove there had ever been serpent worship in Scotiand.

Colonel Lane Fox observed that Mr. Phené had undertaken bis expedition in regard to serpent worship with a foregone conclusion, and the result had been that he had rather disproved his case than otherwise.

The third paper was given by Mr. C. Wake On Man and the Ape. He opened his communication by referring to the physical agreement of structure between man and ape, and angued that the latter animal equally possessed the power of reasoning, and a firmed that man had no mental faculty other than the ape possessed. This paper also led to a hot discussion in which Canon Tristram, the Rev. Mr. Brodie, Rev. Mr. Goodsir, and others joined. Mr. Conway thought that Mr. Wake had been accused of using words such as " nature" and "evolution," which were incapable of definition, but, on the other hand, the department had heard bandied about such words as " creation, ${ }^{4}$ equally incapable of definition. The tdea that something was produced out of nothing was just as vague an idea, he contended, as that of " nature" or "evolution,"

Prof. Struthers, as a person accustomed to dissect men and quadrupeds, said that apes were very like ourselves. He had always regarded this man and monkey question as a very smallone, he meant to say, it was only part of a much larger question. If similarity of structure was to prove origin, they must take in a very large portion of the animal kingdom, all made on the same general plan. He looked upon the theory of evolution simply as an hypothesis. He did not think that facts woald at present warrant a belief one way or the other, though at the same time there were parts in the human boty which we could not understand on the theory of man having been an indepenclent and original creation. We had within our bodies structures which have no function, and which cannot be explained without going down to the lower animals. He did not say they had spring from them, but he affirmed the question was not one to be buadled out of doors in the way desired by some reverend friends. $\mathrm{He}$ should like to say to bis theological friends that scientific nnen did not, in the examination of these laws, shut the Creator out, it was only the modus opterandi, the mode of proceeding, which was the subject of inquiry.

Mr. G. Harris read a paper On the Heralitary Transmission of Endowements and Qualities.

Dr. Charnock and Dr, Carter Blake contributed a paper Ont the Physical and Philological Characteristics of the Wallons, showing that the ordinary Wallons stood in a similar relation to Belgium to that which the Irish peasant did to the "Sassenach" of Enrland. As evidence of their peculiar character, a Wailon would drag a pig from Namur to Ghent, or even to Bruges or Antwerp, in order to gain a few more sots than he could in his own district. The Spanish armies in the Pay-Bas were made up of Wallons. A special mental and moral character might be predicted of the Wallons of each district. The language was a spoken, not a written one, the pronusciation differing in different lucalities.

Mr. G. Petrie read a paper On Ansicnt Modes of Sepulture in the Orknoys. He said sepulchral mounds wure there very frequent, generally on elevations. The skelețons were often discovered in a sitting posture. Mr. Flower remarked that the sitting posture of the skeleton was an interesting discovery, as it had been observed in every country in Europe, as well as in Peru, India, and Africa. Herodotus, in his account of the Autocthones, a people inhabiting what is now the province of Tunis, shows that they always placed their dying friends in a sitting posture to await their last hour, and it seems that they so buried their dead, as they were now found in the old African sepulchres in the same position.

The next paper was a cornmunication received from Mr. J. Wolfe Murray, On a Cross traced upon a Hill near Pestles.

\section{SECTION E.}

Most of the papers in this section were purely geographical, having but little reference to Natural Science. Among the most interesting read on the first day, August 3, was one by Mr. Clements Markham on The Somali Coast, contributed by Captain Miles. The paper contained some interesting information in reference to the trade in gum and aromatic spices, as it has been carried on by the natives from ancient times. Mr. D. Hanbury, alluding to a statement in Captain Miles's paper, that in ancient times frankincense was held to have come from Arabia, and from the adjacent coast of Africa, said that, while this was the case, they were tanght in all the books that hat appeared on the subject in the latter part of the last century, and in the whole of the present till within the last few years, to believe that frankincense was a product of India. It was very desirable to have information on this highly interesting subject. With regard to the different species of gum trees, their information was very poor, and as to myrrh it was even more so. Muclu had been written as to cinnamon, early authors holding that it was a production of Africa and Arabia. It was a very interesting question, and one which required elucidation, whether the cinnamon mentioned in Holy Writ was the production of Africa and Arabia, or whether it was merely carried thither from India, or from the still remoter regions of Siam and China by way of commerce, and whether in that way the idea was promulgsted that it was produced in the land and districts from which it was shipped, by way of the Red Sea, to Europe.

Mr. Clements Markham also read a paper contributed by Captain Elton, on The Limsono Expedition. Captain Elton, who was formerly an officer on Lord Strathnairn's staff in India, undertook the expedition for the purpose of discovering whether the river vas navigable to the sea-a point of great importance, on account of the discovery of gold on the banks of the Tati, one of the upiper tributaries. Capton Elton's canoe was wrecked, and his journey, amounting to upwards of 900 miles-bad to be completed on foot.

One of the most valuable papers in this section was one by Dr. J. D Hooker, descriptive of the botanical features of The Allas Range, the main features of which we have already chro nicled. Dr. Cleghorn stated in the discussion which followed, that, like everything else done by Dr. Joseph Hooker, this investigation had been carefully and thoroughly carried out, and a great deslderatum of botanical knowledge had been obtained. The ahsence of primroses, gentian, and anemones was most remarkable. The observation on the exhatisted condition of the forest was also noteworthy.

Commander A. Dundas Taylor, Jate of the Indian Navy, contributed a paper on The Propesed Ship Camal befween Crylon and India. With the Alderney and other Btitish Parliamentary harbour discussions before the eyes of their understanding, permission, he thought, might perhaps be readily accorded to a student of thirty years in Indian hydrography to bring before the Association his views concerning the proposed scheme. After giving a sketch of the various projects that had been put forward for making a navigable passage between Ceylon and the Indian continent he proceeded to say that the project for deepening the Paumben Passage for large ships had been set aside by its own advocates in favour of the Port Lorne scheme, which bad such remarkable advantages as to claim the attention of the Governments and mercantile communities of Bengal, Madras, Bombay, and Ceylon. An interesting discussion followed, in which the President and Sir E. Belcher joined.

The next morning the first paper was one by Mr. E. H. Palmer On the Grography of Moab. A grant of rook, was made by the Association last year, on the recommendation of this section, to promote the exploration of $\mathrm{Moab}$, and though that grant had not been sufficient, and in consequence the exploration had been deferred, Mr. Pnlmer's paper explained what was already known of Moab, and what had been previously done in its ex. ploration.

Captain H. R. Palmer. R.E., contributed a paper $O n$ an Acoustic Phenomenton at Fabal Nagus, in the Peninsula of Mount Sinai ; and Dr. Ginsburg made a verbal communication in reference to a treatise On Farther Disclosures of the Moabile Slone. This treatise referred chiefly to the history of the stone.

On Saturday, August 5, a communication was read by StaffCommander George, R. N., Ont a Nezu Antificial Horizon. The old artificial horizon, with its roof, trough, and bottle of quicksilver, was bulky, heavy, and often very inconvenient to carry; while the 
more convenient one with a folding roof is still open to the same objections as regards bulk, weight, and inconvenience. Yet an artificial horizon is an absolutely essential part of a traveller's equipment, so that any improvement in its construction is sure to be welcomed. Captain George's instrument is atated to combine all the advantages of the larger and more cumbrous horizon now in use, together with the additional property of securing observations at very low sltitudes. The improvements are not confined to its reduced size and weight, but extend to its mechanical arrangements, fotm, and moderate price. The new horizon weighs $\mathbf{I} \frac{1}{6} \mathrm{lb}$, while that now in use weighs $6 \frac{7}{2} \mathrm{lbs}$. The self-replenishing horizon consists of two circular disc-like reservoirs, about $2 \frac{1}{\mathrm{t}}$ inches in diameter, and three-quarters of an inch in depth, made of iron in one casting. One contains the mercury, and the other is the trough, fitted with a glass cover for observing. The discs are connected at their circumferences by a narrow neck, with a hole drilled through it, by which the mercury passes from one reservoir to the other, communication being opened or cut off by a stop-cock, without removing the glass cover, or running the risk of losing any of the mercury.

A paper by Major Basevi, On the Minicoy Islastd, was next read. Major Basevi, who is connected with the Great Trigonometrical Survey of India, visited the Island of Minicoy, with the object of comparing the intensity of gravity on an island station with that at inland stations in the same latitude. Minicoy is a small coral island, in shape somewhat resembling a crescent, and about $6 \frac{1}{2}$ miles long. The whole of the island is covered with cocoa plants, which are the chitf source of wealth to the inhobitants, all of whom have their own trees--the rich as many as $2, \infty 00$. The village of Miricoy is situated nearly in the middle of the istand on the west side. It is half a mile long and contains about 300 houses, built of coral rock, cementes with lime and thatched with palm leaves. The result of Major Bascvi's observations on the Island of Minicoy was the conciusion that gravity on the coast is greater than inland, and at an ocean station like Minicoy greater than on the coast. It was already known that at inland stations gravity appeared to be in defect of that observed at const stations in similar latitudes; and, by including the ocean station of Minicoy in Major Basevi's series, a confirmation of the law has been obtained.

Captain A. Pallan contributed some notes On British Gurhtral, where he had been employed for four years on the Trigonometrical Survey ; and Mr. Samuel Mossman a paper On the Inundation ant Subsidence of the Yangtze River.

Mr. Clements Markbam read a raport On Badokshan, by Bandit Manphul; and a description of a journey from Yassin to Yarkhand, by Ibrahim Khan. The most interesting feature in connection with these papers was that they confirmed the surveys of the country made in 1838.40 by Captain Wood of the Royal Navy. Captain Wood, who is a native of Edinburgh, discovered the river Oxns, and for doing so was aurarded one of the gold medals of the Royal Geographical Society. His surveys were ignored by Prussian and Russian geographers, but were now confirmed by the native travellers who have devoted their attention to the parts of the country in question.

The Rev, F. O. Morris contributed a paper On Encroachments of the Sea on the East Coast of Yorkstire. It was stated that on the average there had been a loss of land of from two to three yards every year-probably about $2 \frac{1}{2}$ to $2 \frac{3}{2}$ yards per annum. If looked at in round numbers, the waste of land, at three yards in each year, would be found to be about thirty-nine acres between Spurn Point and Flamborough Head alone, or in a hundred years of 3,900 acres, which, at a value per acre of 30 . or 5ol., would represent a serious money loss of grain or other crops ; or, taking the waste, as had been calculated, at one mile since the date of the Conquest (ro66), the money value in that interval, at 30. . per acre, would be equal to $69 \mathrm{r}, 200 \mathrm{l}$, , or at 50 an acre no less that 1,152,00o. Mr. Morris concluded by saying there was no donbt whatever that a sea-wall of roughly-hewn, or even unhewn, stones, laid on an angle of about thirty-five degrees, would for ever protect the land from encroachment.

\section{'SECTION F.}

THe papers and discussion in Section $\mathbf{F}$ are searcely of a nature to come within the range of a report in NATuks. Occasionally, however, they may well find a place, as when on the first day Sir Joln Bowring read the Report of the Metric Comsnittec of the British Association. The Committce were much gratified at the larse amount of information the Royal Commissioners had collected in regard to the metric system, but regretted that the Commissioners had not recommended a bolder course than the permissive legislation of its use. The Commissioners assumed there was no immediate cause requiring a general change in the existing system of legal weights and measures of the country for the purposes of external trade, but they had not sufficiently taken into account the bcarings of the question on education and scientific workmanship, and the general economics of the nation. The committee admit that the fult realisation of the advantages of the system must be the work of time, but all the more necessary is it to make provision for the same by inserting in any measure on the subject clauses fixing a time when the use of the new system will become binding. Pending the final settlement of this important question, the committee are gratified in finding that the Educational Code of this year for the first time prescribes that in all schools the children in Standards V. and VI. in arithmetic should know the principles of the metric system. The committoe are convinced that the school is the proper place for initiating this aseful reform, and urge that teachers should at once commence to introduce this subject in the schools. The committee have represented to the London School Board the desirability of introducing the metric system into its schools, and will correspond in a similat manner with other school boards. In order to diffuse information on the subject, the commictee suggest that they should bo re-appointed, with a grant of at least 75 l, from the funds of the Association. After some discussion, the report was accepted-it being understood that no opinion was expressed on the compulsory question. On the same day the Report of the Commiltee for the Tabulation of the Censal was read by Mr. Fellowes. It stated that various suggestions had been made to Mr. Bruce, with the view of having tue returns from the various parts of the kitugdom tabulated in one unilorm method, and the committee had reason to believe that the recum. mendation in their memorial would ultimately, to a considerable exient, be adopted by Her Majesty's Government.

After the reading of Mr. Fellowes's paper On a Proposed Doonsday Book, giving the value of the Governmental property, as a basis for a sound system of national finance and accounts, Mr. T. J. Boyd, master of the Merchant Company, read a paper On Educational Hospital Reform ; the Scheme of the Edint. burgh Merchant Company. The object of this paper was to illustrate, from whit had been done by the Merchant Company in recent years, the manner in which similar foundations might increase their use.ulness and extend the benefits contemplated by the founder.

On the following day Col. Sir J. E. Alexander read a paper On Sanitary Measucres for Scottish Villages. Among the evils pointed ont as existing in these villages were the overcrowding of cottages, the system of "box-beds", in which father, mother", and children might often be found huddled together, the builtzin windows quite incapable of being opened, the general want of air and ventilation, and the proximity of cow-sheds and pig-sties. The writer showed how ministers, surgeons, schoolmasters, and employers might promote the welfare of the people by inculcating the laws of health, and promoting a taste for pure and innocent recreations.

One of the most interesting episodes in this section occurred on Saturday, when the reading of a paper by $\mathrm{Mr}$. George Smith, On Indiant Statistics and Official Keports, gave occasion to the following remarks on Indian education by a native Hindoo, Mr. A. Jyram Row. A great element in the success of the schemes for the better educntion of the Indian population was the nature of the educa tion which must in future be given to the natives of India, At present it was certainly of a character calculated to do a great deal of good, but at the same time it was restricted to English literature and mathematics. Now, the mere reading of Shakespeare, and the mere cramming of a few propositions from Euclid, would never enable people to embrace large questions of speculative and scientific interest, which alone could be expected in the end to lead to any practical result. Without sucl an education these statistical schemes would seem at first sight to have nothing to do with anything that wras practical; unless it were (as some people supposed) that they merely had reference to the imposition of a poll-tax or some such thing. They could not see (and it was not to be expected that people unaccustomed to scientific questions and the bearings of each department of science upon the solution of problems entirely unconnected with the department could see) that such schemes would be of the highest conseculence towards the material welfare and progress, 
not only of Hindostan, but of every nation on the globe. Therefort, he was of opinion that such an influential bocly as the British Association would do well to exert its inflaence in obtajning for the natives of Iudia a more thorough scientific education.

The time of this section on Monday, August 7, was chiefly occupied by debating the administration of the Poor-law Reformatories and kindred subjects not suiled to our columns. In a paper on the Scientific Asprets of Children's Hospitals, Dr. William Stephenson endeavoured to show how far their general management tended to promote the twofold object for which they were called into existence-namely, the relief of the children of the poor and scientific instruction in the diseases of children-and what external causes were at work to check the full development of the influences they exeriec. He pointed out the importance of such institutions as the Sick Cnildren's Hospital, in the way of extending the knowledge of the diseases of children among students of medicine, and also in the way of training nurses both for the hospital and for the family.

On Tuesday, the paper which excited the greatest interest and most animated discussion was by Miss Lydia Becker, On tome Maxims of Political Econony as applied to the Emplomment of Women and the Education of Girls; and this was followed by one on Naval Efficiency and Dorkyard Economy, by Mr. Charles Lamport, and by others on Land Tenure and the Assessment of the Foor, concluding the business of this section.

\section{SECTION G.}

ON the opening day of the Association, Mr. Thomas Stevenson, C.E., in introducing the subject of a Proposed Auto: matic Gange for the Discharge over Waste Weirs, said that in order to ascertain the amount of available rainfall, which was so important in questions of water stpply, it wns necessary to gauge the quantity of water which escaped at the waste weirs of reservoirs. Observations made only once or twice a day could not supply the information. He proposed to place a tube perforated vertically with small holes, the lowest of which was on a level with the top of the waste weir, so that whenever water pased over the weir, it also passed througl the lioles in the tube. The water was collected in a tank capable of holditig the dis: charge for a certain number of hours. The quantity so collected was a known sabmultiple of what passed over the weir. The discharge through the holes was ascertained by experiment.

In the discussion which folloved, different views were expresser as to the practical value of Mr. Stevenson's proposal, which was, however, favourably regarded by Prof. Ramkine.

A paper on $A$ New Form of Salmon Ladders for Reservoirs was read by Mr. Alexander Leslie, C. B. The new form of salmon ladders for reservoirs of varying level, a model of which was exhibited, contemplates that on all occasions the whole outflow required to run down the stream should be through only one sluice gt at time, and over the top of that sluice, which would open by lowering, and shut by being raised, except in extreme tloods, when, for the sake of keeping down the level of the lake, so as to avoid flooding the adjoining lands, or when from any other exceptional reason, such as an accumulation of ice, it may be necessary to provide a lower outlet or the means for a more rapud discharge. Assuming the rise of the lake to be 12 feet, and that it is full, or up to the level of the waste weir, the uppermost sluice is opened, so that the water may flow over it to the depth of, say, from 9 to 12 inches, and then run down the inclined plane of, say, Io feet in width, composed of a series of pools formed by stops reaching quite across from wall to wall, the fall from surface to surface of those stops being 18 inches, and the depth of each pool being not less than 3 feet. The fish may then easily leap over the successive falls, seven in number, after which they must take the last leap over the sluice into the lake, the last leap being at first like all the rest, 18 inches, but diminishing in beight as the level of the lake is lowered, till at last it is nothing, when the level of the lake comes to be the same as that of the pool. The paper went on to describe the process of the working of the requise when the lake gets to supply of water over the top, and concluded by stating tbat it would be preferable not to make the ladder above 18 inches $\mathrm{On}$ that point, however, the author did not offer any decided opinion, but left it an open question.

The next paper was by Mr. R. A. Peacock, C.E., Jersey, on A Chain Cable Testing and proposad $N$ :av Link. The paper proposed to provide a new testing link, which, it was believed, wonkd be found useful in yarions ways. I he following is a description for a colle of which the metal would be one inch in diametur:Let the cable manufacturer provide himself with a number of p'ales of rolled iron, of the same gual ty as the cylindrical bars of iron of which the ordinary links are made. The thickness of each plaie is to be equal to th: diameter of the bar from which it is provided. Eight links will have to be pancjed ont of the plates by meins of a steam punch. One new link, when filed half round, will be placed longitudinally at each extremity of the cable, with which it will be connected. A new link, after being filed as aforesaid, will be inserted longitudinally at every fifteen fathoms in each cable, so as to form a part or parts of the cable ; and each cable being about 150 fathoms long, will require eight new links.

A paper On Rond Steanters, by Mr. R. W. Thomson, Edin. burgh, was read by Mir. Miall. In the outset, the paper allnded to the importance of road steamers and the difficulties which had been encountered in arriving at the present stage of perfecion with these machines. A uniformity in the working of the engine having been reached, a thick carpet of india-rubber for the tires of the wheels was introduced, which much improved the running on roads. These india-rubber tires not only completely prevented hard shocks to the machinery, but saved the road from the grinding action of the iron wheels which was so injurious to by-ways. There had been serious objections made to the use of these engines by people interested in the roads, but the author could assure them that the india-rubber tires actually improved the roads. The paper went on to refer to rigid tires as used for road steamers, and stated that the amount of adhesion obtained by this ire was much less than by the india-rubber kind. The latter kind took a firm hold of the road, whatever might be the nature of the surface. The only ground upon which india-rubber tires did not work well was where the soil was extremeiy wet or of a very soft nature. For farm work the wheels of the engine required a much thicker coat of india-rubber.

Mr. Robert Fairlie read a paper On the Gavere of Railways. The author argues for the narrower gauge, and says :-Experience has shown that $3^{\text {ft }}$ 6in. can be made a highly economical and efficient width, but it does not by any means follow that it is the most scrviceable and most efficient, any more than it follows tbat the accidental 4 ft. 8 fin. was all that could be de-ired, even though an Act of Parliament had made it an asticle of belief. On the contrary, as our knowledge and experience incresse, we are enabled to approach more and more nearly to that happy mean on either side of which is error. While, on the one hand, there is every necessity for obtaining such a gauge as will afford a good and useful width of vehicles, on the other it is necessary to avoid such narrow limits as would necessitate the introduction of too great overhaug on each side of the rails. The 3 ft. gange appears to me to comply with all the necessary conditious better than any other, and it is from no mere theorising that $I$ lend all the influence I have towards its adoption. There is a certsis amount of saving in first cost as compared with the 3 fr. 6in., not a large amount, but worth considering. This, however, I leave out of the discussion for the present. The all-important matteri are to place upon the rails a thoroughly efficient stock that shall posiess a maximum of capacity and a minimum of weight, and to supply engine-power under tire most economical circurnstances, and I hold it to be casier to accomplish these objects on the $3 \mathrm{ft}$. gauge then upon any other. I am led, to this conclusion both by a comparison of the actual work done on the railways of the $3 \mathrm{ft}$. $6 \mathrm{in}$. gauge, with that which can be accomplished with the $3 \mathrm{ft}$. gange, and because, having in view the practical requirements of goods traffic, I find that I can obtain an ample floor area with less dead weight than can be secured by any other width; on a wider gauge the dead-weight increases, on a narrower one the capacity diminisbes. He quoted figures to show that to carry so tons of goods on the Norwegian or Queensland $3 \mathrm{ft}$. 6 in. gauge, the proportion of one ton per waggon being preserved, 92 per ceat. of the weight of rolling stock used on the 4 it. 8 tin. would be required; as against only 43 per cent. on a 3 ft. gature, showing \& saving of 47 per cent. on the latter as compared wich the $3 \mathrm{ft}$. $6 \mathrm{in}$. Of course, if the wargons were loaded up to full capacity, these percentages w'ould be very much changed. It is to this point especially that I wish to direct your attention, as upon it the economy of the

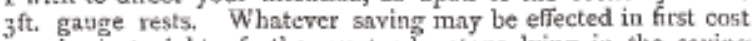
may be lost sight of, the great advantage lying in the saving effected in working expenses. Every ton of dear weight saved goes towards securing the prosperity of the line, and if we can obtain the ample platform which the 3 th. gauge gives, combined with so much soving in weiglat, nothilg is iett to be desired. 
A paper on a New Systeme of Warming and Ventitation by Mr. J. D. Morrison, was read. The main features of the system consist in so circulating fresh air through a warming cbamber into the room, and foul air through the tire into the chimney, that all local currents are resolved into one, which forms an upper warmer current from the fire to the opposite wall, and an under colder current from the wall back again to the fire, when, after supporting combustion, the products escape up the chimney. The vacuum thus produced by the warmer current tbrough the chimney creates the now colder current from the atmosphere, which, passing through the heating chamber, supports the respiration of any number of persons.

On Friday, August 8, Mr. A. E. Fletcher, F.C.S., read a paper On the Rhysimeler, an instrument for indieating the velocity of flowing liquids, and for measuring the speed of ships through the water. The principle on which it is constructed resembles that of the anemometer, recently brought into notice by Mr. Fletcher, by which he is uble to measure the speed of hot air, flame, and smoke, furnace flues and factory chimneys. Both in the anemometer and in the raysimeter, the impact force of the current, and also its tendency to induce a current parallel with itself, are measured and made to become indicators of the force and velocity of the stream. The apparatus is very simple. A componad tube with two orifices at the bottom, one of which faces the source of the current, while the other faces the opposite direction, is held in the stream, and communicates by tubes with the indicator where the pressure is measured by columns of ether, water, or mercury, according to the circumstances of the case. When used to measure the velocity of a brook or open stream of water, the speed at any depth or at any portion of its surface can be separately estimated. For taking the speed of water in pipes it is only necessiry that there should be suitable cocks screwed into the pipes at the required places; through these the "speedtube" of the rhysimeter passes without allowing any escape of water, whntever may be the pressure. A still more important water, whation of the instrument is to measaring the sperd of ships. Here the speed-tube pierces the bottom or sile of the ship, and projects a fow inches into the water outside. The indicator may be in the captain's cabin. It resembles in size and appearance a barometer. In it a culumn of mercury indicates contintially the speed of the ship. The full effect of the velocity is imparted ts the mercury, without loss by friction or otherwise, so that the fidication must always be absolutely correct. The instrument may be made self-registering, shuwing by a dial the total num. ber of knots the ship has run since she left port, and marking on a sheet of paper the speed attained at every portion of the time. This permanent register may, in many cases, be of the greatest value. The paper was illustrated by diagrams, and by tables showing the velocities in knots per hour, or in feet per second, for the various heights of the columns of 'water or mercury.

Admimal Sir Edward Belcher said the principle was very valuable, but he did not see the necessity of passing the tube down so far below the water. He thought one or two inches would suffice.

Prof. Rankine said the principle of the instrument was an old one, and the anthor, he believed, admitted this. Mr. Fletcher had overcome a series of inconvenient and difficult details, and had produced an instrument which had actually been applied to practice with satisfactory results." He belived that the instrument would be a good substitute for the old log system of ascertaining the speed of a ship.

This section did not sit on Saturday.

\section{SCIENTIEIC SERIALS}

THE article in the Quartorly Fournal of Science for July which will be most read, is by the ellitor, Mr. Crookes, "Experimental Investigation of a New Force," on which we haye already conn. mented. "The Dawn of Light Printing" gives a sketch of the early discoveries in photography of Niepce, Fox Talbot, and Daguerre. Mr. F. C. Danvers gives an account of the present condition of inventions for Pneumatic Transmission, with mathentatical formule for the power obtained. Under the title "Where are the bones of the Men who made the unpolished Flint Implements?" Mr. Pengelly argues that we know so little aloout the effect of various climatic and atmospheric condinions on the boves of man and the lower animals, that it is rash to con- clude, because human remains are not, as a rule, found associated with flint implements and animal remains in the hone caves, that therefore they canaot have been originally deposited along with them. $\mathrm{He}$ also cites a number of unquestioned instances in which the bones of man have been found in such situations, to all appenrance contemporaneous with the animal remains, Even were such evidence entirely wanting. Mr. Pengelly considers the flint implements themselves absolutely conclusive proof of the contemporaneity of man wish the mammoth and the extiuct cave-animals. One of the most valuable and interesting articles in the number, though a short one, is entitled "A New Mechanical Agent : A Jet of Sand." Mr. B. C. Tilghman, of Philadelphia, appears to have solved the problem of cutting or carving, mechanically, hard substances, such as stone, glass, or hard metals, in an expeditious, accurate, and economical manner. He has shown that a jet of quartz sand thrown against a block of solid cormedun will bore a hole through it one and a half inches in diameter and one and a half inches deep in twenty-Give minutes, and this with a velocity obtainable by the tse of steam as a propelling power at a pressure of $300 \mathrm{lbs}$. per square inch. The apparatus used for grinding or culting glass or stone is described in detail. By covering parts of the glass surface by a stencil or pattern of any tough or elastic material, such as paper, lace, caoutchouc, or oil paint, designs of any kind may be engraved upon ir. In his absiracts of the Progress of Science, the editor now confines himself entirely to the physical branches.

THE American Naturalist for August contains bo one very striking paper, though several of consioerable interest. Dr. J. S. Billin;s contributes a mycological paper on the "'Study of Minute Fungi," and Mr. A. S. Jitchie one, entitled "The Toad as an Entomologist," showing the very large number of insects which that animal destroys. On one occasion the writer found thirteen perfect insects in the stomach of a toad belonging to nine species, besides one elytron each of two others, and other vestiges of legs and wings. He concludes that the toad is of great service to agriculturists.-Prof. Lesquereux has an article on the "Mode of Preservation of Vegetable Remains in the American Coal Measures," an important article on verretable palieontology; and Alexander Agassiz a short paper on "Systematic Zoology and Nomenclature," indicating the great importance of a correct system of nomenclature as an item in the history of zoology.

THE Western Chrorticle of Science for July 1871. Edited by J. H. Collins, F.G.S. Nos. I-7. Falmouth, W. Tregaskis,-We have much pleasure in noticing the first seven numbers of this local scientific periodical, and sincerely hope it will not be allowed to drop from want of subscribers, of which the editor complains. It should be encouraged by al! lovers of scientific inquiry, not only in the western district but throughout the country. Its jow price, only twopence, puts it within the reach of all, while at the sacne time a large circulation is required to make it pay. The seventh number contains an interesting paper, valuable both to architects and geologists, on the ornamental rocks of Devon and Cornwall, counties abounding in beds of vari-coloured limestone sufficiently hard to receive the polish of marble. The second is a most nell. sible and judicious paper on the duties of locsl societies. If the sniggestions bere made were carried out in all societies, an interest in physical science would soon become universal. Betiles other marters, the number contains the results of the May examinations in science, so far as thesic concern the classes in the We t of Cornwall. A larke proportion seem to have passed in the various sabjects, the total number of successful candidates being 69 .

SINCe the commencement of the Revue Scientifique, it has continued much the same course as its predecessor the Revue des Cours Scientifigues. Seven numbers are now before us, containing among others, the following articles, besides reports of lectures or extracts from the proccedings of various learned socjetics at home and abroad:-Van Reneden on Commensatism in the animal kingdom, Ancienț Chutches by M. Ch. Contejean, Geographical disiribution of the Balense by Van Beneden, Physico-chenical researches or Aquatic Articulates by M. Felix Plateat, M. Chauvean's Report on Science and Legislation in relation to the Cattle-plague in France, M. Claude Bernard on the Influence of External Heat on Animals, Accounts of the Life and Writings of M. Claparede and Prof. Payen, M. Pasteur's address, "Why France did not find superior men in the momeat of peril," the addresses delivered at the Liverpool meetings of the British Association by Huxley, Tyndall, and Rainkine, and repo.ts of some of the sectional procecdings. 